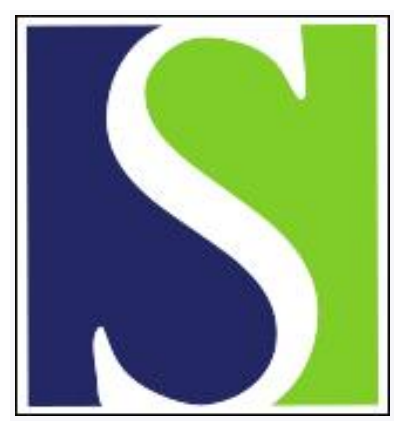

Scand J Work Environ Health 1980;6(4):291-298

https://doi.org/10.5271/sjweh.2606

Issue date: Dec 1980

Chromosome aberrations and sister chromatid exchanges in Swedish paint industry workers.

by Haglund U, Lundberg I, Zech L

Key terms: chromosome aberration; organic solvent; paint industry worker; sister chromatid exchange; Sweden; toluene; xylene

This article in PubMed: www.ncbi.nlm.nih.gov/pubmed/7233117

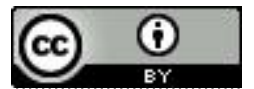




\title{
Chromosome aberrations and sister chromatid exchanges in Swedish paint industry workers
}

\author{
by Ulla Haglund, BSc,' Ingvar Lundberg, MD, ${ }^{2}$ Lore Zech, PhD ${ }^{1}$
}

\begin{abstract}
HAGLUND U, LUNDBERG I, ZECH L. Chromosome aberrations and sister chromatid exchanges in Swedish paint industry workers. Scand $j$ work environ health 6 (1980) 291-298. Workers in the Swedish paint industry exposed to a mixture of organic solvents, mainly containing xylene or toluene, were investigated for genotoxic effects. No difference in the frequency of sister chromatid exchanges (SCE), 0.192 and 0.193 per chromosome, respectively, was noted in the peripheral lymphocytes of the exposed group of 17 workers and their matched reference group. No correlation was found between xylene or toluene exposure and SCE frequency nor between total solvent exposure and SCE frequency. The frequency of chromosome aberrations was also investigated for the five most exposed workers and their matched referents, and no difference was found. There was no correlation between SCE and chromosome breaks.
\end{abstract}

Key terms: organic solvents, toluene, xylene.

Several aromatic solvents have proved to exert genotoxic effects. An increased frequency of chromosome aberrations due to benzene exposure is a well known phenomenon $(7,8,14,17,30)$. Styrene exposure has also been found to induce chromosome aberrations $(6,21)$, while results concerning exposure to toluene are controversial. Funes-Cravioto et al (10) reported an increase of chromosome aberrations after toluene exposure, while Forni et al (8) did not find an increase in the frequency of chromosome aberrations in humans after such exposure. With respect to sister chromatid exchanges (SCE) no increase could be found in two of these studies, in which workers exposed to toluene (10) and styrene (21) were found to exhibit excess chromosome aberrations. However, this finding might have been due to the ex-

1. Department of Medical Cell Genetics, Medical Nobel Institute, Karolinska Institute, Stockholm, Sweden.

2 Department of Occupational Health, National Board of Occupational Safety and Health, Solna, Sweden.

Reprint requests to: Ms UIla Haglund, Department of Medical Cell Genetics, Karolinska Institute, Box 60400, S-104 01 Stockholm, Sweden. tremely limited sizes of the populations examined with the SCE technique.

To our knowledge, there are no studies of genotoxic effects on workers exposed to xylene or mixtures of common organic solvents used in paints. In a report by Ulfvarson (31) it was shown that workers in the Swedish paint industry are exposed to a mixture of organic solvents, xylene often being a main component of the mixture. The solvent air concentrations were rather high in all parts of the factories. Some workers engaged in the manual cleaning of equipment with solvents were exposed to extremely high concentrations.

We have studied SCE and chromosome aberrations in a group of Swedish paint industry workers.

\section{Materials and methods}

\section{Subjects}

Seventeen male paint industry workers were included in the study. They were employed in seven different factories in the southern part of Sweden. The participants were selected as those with the presumably greatest exposure from a group of 47 paint 
Table 1. Detected solvents and their respective threshold limit values (TLVS), number of persons exposed to each solvent, median exposure values for those exposed and exposure ranges. All exposure figures are expressed as 8 -h time-weighted averages.

\begin{tabular}{|c|c|c|c|c|}
\hline Solvent & $\begin{array}{c}\text { TLV } \\
\left(\mathrm{mg} / \mathrm{m}^{3}\right)\end{array}$ & $\begin{array}{l}\text { Number of sub- } \\
\text { jects exposed }\end{array}$ & $\begin{array}{l}\text { Median expo- } \\
\text { sure value } \\
\left(\mathrm{mg} / \mathrm{m}^{3}\right)\end{array}$ & $\begin{array}{c}\text { Exposure range } \\
\left(\mathrm{mg} / \mathrm{m}^{3}\right)\end{array}$ \\
\hline Xylene & 435 & 16 & 111 & $14-6,074$ \\
\hline Toluene & 375 & 16 & 11 & $1-1,257$ \\
\hline Isobutanol & 150 & 15 & 5 & $1-354$ \\
\hline Ethylacetate & 1,100 & 14 & 20 & $1-129$ \\
\hline n-Butylacetate & 710 & 13 & 14 & $7-1,676$ \\
\hline Ethanol & 1,900 & 13 & 13 & $5-971$ \\
\hline n-Butanol & 150 & 13 & 7 & $1-1,541$ \\
\hline Methylacetate & 610 & 8 & 12 & $3-169$ \\
\hline Methylene chloride & 350 & 3 & 719 & $635-2,421$ \\
\hline White spirit & 600 & 3 & 45 & $5-\quad 52$ \\
\hline Isopropanol & 490 & 1 & 129 & \\
\hline
\end{tabular}

industry workers who were examined in a more extensive medical and psychophysiological investigation. The results of that investigation will be reported elsewhere (Anshelm-Olsson to be published, Lundberg to be published).

A referent, matched by age, sex, place of residence and smoking habits, was chosen for every exposed participant. The place of residence was defined as rural or urban, while smoking habits were described with the categories smoker and nonsmoker. The majority of the referents was selected from factory workers working in storerooms, but also other occupations such as paint grinders, electricians, drivers and carpenters were represented. They were not exposed to solvents or known mutagens.

Conventional blood counts and liver enzyme tests were performed for every participant and found to be within normal limits. The ages of all the subjects can be found in table 2, where also the duration of employment in a solvent-exposed environment can be found.

\section{Exposure}

Air from the breathing zone of every exposed subject was collected with batterydriven syringes, each representing about 30 min of exposure during a complete workday. The contents of the syringes were analyzed with two $\mathrm{AID}^{\circledR}$ portable gas chromatographs with flame ionization detectors. Steel columns were used (length 2 $\mathrm{m}$, internal diameter $0.32 \mathrm{~cm}$ ), and they were packed with Chromosorb C $(60-80$ mesh) coated with $2 \%$ Carbowax 400 or Chromosorb WHP (80-100 mesh) coated with $10 \%$ DC 200. The column temperatures were 60 and $100^{\circ} \mathrm{C}$, respectively. The exposure measurements took place in the period March - October 1978.

Altogether, 11 solvents were detected in the air. They are listed in table 1, together with the number of subjects exposed to each solvent, the median exposure values, and the exposure ranges. All exposure figures are expressed as the 8-h timeweighted average (TWA). The Swedish 1978 threshold limit values (TLV) are also included. It is obvious that exposure to xylene was predominant in many cases. However, toluene exposure was also often important, even though the median exposure values did not reflect it. Seven subjects were exposed to a toluene concentration of more than $100 \mathrm{mg} / \mathrm{m}^{3}$. The hygienic effect $t^{3}$ was used as a measure of the total solvent exposure. The median value of the hygienic effect was 0.5 with the range $0.1-40$.

3 The hygienic effect is defined as the sum of the fractions of the respective TLV that each solvent represents. For example, in our case, combined exposure to concentrations of 30 $\mathrm{mg} / \mathrm{m}^{3}$ isobutanol, $87 \mathrm{mg} / \mathrm{m}^{3}$ xylene, and 660 $\mathrm{mg} / \mathrm{m}^{3}$ ethyl acetate means exposure to a hygienic effect of 1 . 
Blood sampling, lymphocyte culturing and slide analysis

The blood samples were collected during the period March-May 1978. The blood was obtained from a cubital vein and collected in heparinized Vacutainer tubes. Blood samples from both the exposed and reference subjects were collected at the same time. Samples from outside the Stockholm area were mailed to the laboratory. Samples from 11 pairs, including the samples from the persons with the greatest exposure, were taken on Thursdays. All the persons in these pairs had worked as usual the day before the samples were obtained. Samples from the six other pairs were taken on Mondays, the exposure-free period being about $60 \mathrm{~h}$ in these cases. In all cases the analysis procedures started the day after collection, simultaneously for the two persons in each pair.

Phytohemagglutin-stimulated lymphocytes were cultured for $72 \mathrm{~h}$ both for the SCE and chromosome abnormalities in medium RPMI 1640 with L-glutamine added. For the SCE studies, bromodeoxyuridine $\left(4 \times 10^{-5} \mathrm{M}\right)$ and fluorodeoxyuridine $\left(10^{-5} \mathrm{M}\right)$ were present during the whole culture period, and the cells were kept in the dark and handled under a red photosafe light. The cells were harvested according to our standard scheme (13). For the scoring of the SCE, the slides were stained according to the fluorescence plus Giemsa technique (22), and for the scoring of the structural and numerical chromosome abnormalities, they were stained with quinacrine mustard (4) and photographed. The photographic negatives were analyzed in a television set equipped for contrast enhancement (3). The SCE slides were analyzed directly via a microscope in a similar television set (5).

From each individual, 20-25 metaphases were scored for SCE, and about 100 metaphases were scored for chromosome aberrations for each of the five workers with a hygienic effect above 1 , as well as for their referents. The slides were scored blindly.

SCE occurring in the centromeres were included in the calculations, but obvious twists were excluded. When the chromosome aberrations were scored, only cells with 45 or more chromosomes were in- cluded. Only cells with more than 46 chromosomes were considered as numerical aberrations; thus only about half of the real aneuploid frequency was registered. Only those cells with more than 46 chromosomes were scored as aneuploid because chromosomes are easily lost from the metaphase plate during slide preparation. Gaps, defined as nonstaining regions smaller than the width of the chromatid, were not included as aberrations.

\section{Statistical analysis}

For the calculation of p-values, Wilcoxon's rank sum test for paired differences, onetailed, was used, and for the calculation of correlation coefficients the least squares linear regression was employed. The significance test of the correlation coefficients was performed according to Snedecor (29).

\section{Results}

SCE frequencies in the exposed and reference groups

As can be seen from table 2, there was no difference in the frequencies of SCE between the exposed group and the matched reference group, 0.193 and $0.192 \mathrm{SCE} /$ chromosome, respectively. Neither did the comparison of the 10 persons exposed to a xylene concentration of more than 100 $\mathrm{mg} / \mathrm{m}^{3}$ or the seven persons exposed to a toluene concentration of more than 100 $\mathrm{mg} / \mathrm{m}^{3}$ with their respective referents give any significant differences (table 3). Exposure figures for toluene and xylene are presented separately in table 2 because exposure only to these solvents, or in combination in most cases, constituted the main part of the total solvent exposure. This was also the case for the comparison of the individuals with a hygienic effect above 1 and their matched referents (table 3). No correlation seemed to exist between SCE frequency and xylene exposure, toluene exposure, and hygienic effect (table 3). There was no correlation between SCE frequency and age $(r=-0.02)$.

Within groups, a large heterogeneity was found, the chi-square ( $\mathrm{df}=32$ ) equaled 196 for the exposed and 101 for the reference group. The exposed person in pair 
$F$ contributed heavily to the chi-square value. After his exclusion from the material, there was a decrease to a chi-square of 108 for the exposed group.

Effect of smoking on sister chromatid exchange frequency

As it is known that smokers have a higher SCE frequency than nonsmokers (19), the referents were also matched in regard to smoking habits. The frequency of SCE in smokers and nonsmokers (regardless of solvent exposure or matching), 0.202 and 0.175 , respectively, was compared, and a significant difference was obtained $(\mathrm{z}=$ 1.98, $\mathrm{p}=0.02$ ).

Chromosome aberrations in workers with a hygienic effect above 1

An analysis of structural and numerical chromosome aberrations was carried out for the five workers with a hygienic effect

Table 2. Sister chromatid exchange (SCE) frequencies for the exposed persons and referents and exposure figures for the total solvent exposure and exposure to toluene and xylene. Toluene and xylene exposure is presented as the percentage of total solvent exposure on a weight basis.

\begin{tabular}{|c|c|c|c|c|c|c|c|c|c|c|c|}
\hline \multirow{3}{*}{ Pair } & \multirow{3}{*}{$\begin{array}{l}\text { Smok- } \\
\text { ing }\end{array}$} & \multirow{2}{*}{\multicolumn{2}{|c|}{$\begin{array}{l}\text { Age } \\
\text { (a) }\end{array}$}} & \multicolumn{6}{|c|}{ Exposure } & \multirow{2}{*}{\multicolumn{2}{|c|}{$\begin{array}{c}\text { SCE per } \\
\text { chromosome }\end{array}$}} \\
\hline & & & & \multirow{2}{*}{$\begin{array}{l}\text { Dura- } \\
\text { tion of } \\
\text { employ- } \\
\text { ment } \\
\text { (a) }\end{array}$} & \multirow{2}{*}{$\begin{array}{l}\text { Hygien- } \\
\text { jc } \\
\text { effect }\end{array}$} & \multicolumn{2}{|c|}{ Xylene } & \multicolumn{2}{|c|}{ Toluene } & & \\
\hline & & $\begin{array}{c}\text { Ex- } \\
\text { posed }\end{array}$ & $\begin{array}{l}\text { Refer- } \\
\text { ent }\end{array}$ & & & $\mathrm{mg} / \mathrm{m}^{3}$ & $\begin{array}{l}\% \text { of } \\
\text { expo- } \\
\text { sure }\end{array}$ & $\mathrm{mg} / \mathrm{m}^{3}$ & $\begin{array}{l}\% \text { of } \\
\text { expo- } \\
\text { sure }\end{array}$ & Exposed & $\begin{array}{l}\text { Refer- } \\
\text { ent }\end{array}$ \\
\hline A & + & 20 & 21 & 0.8 & 40.0 & 6,074 & 42 & 1,257 & 9 & 0.208 & 0.223 \\
\hline$B$ & + & 21 & 22 & 0.8 & 4.6 & 501 & 28 & 114 & 6 & 0.185 & 0.206 \\
\hline C & + & 23 & 22 & 0.8 & 4.3 & 586 & 35 & 111 & 7 & 0.227 & 0.152 \\
\hline D & + & 28 & 29 & 11 & 1.5 & 133 & 18 & 340 & 46 & 0.224 & 0.183 \\
\hline$E$ & + & 52 & 52 & 13 & 1.3 & 0 & 0 & 379 & 74 & 0.151 & 0.130 \\
\hline$F$ & + & 63 & 65 & 34 & 0.9 & 115 & 25 & 188 & 40 & 0.321 & 0.214 \\
\hline$G$ & - & 58 & 58 & 44 & 0.8 & 89 & 21 & 134 & 31 & 0.134 & 0.164 \\
\hline $\mathrm{H}$ & - & 58 & 58 & 44 & 0.5 & 107 & 42 & 12 & 5 & 0.177 & 0.166 \\
\hline 1 & + & 58 & 58 & 8 & 0.5 & 178 & 77 & 1 & 0 & 0.165 & 0.258 \\
\hline J & + & 27 & 26 & 13 & 0.5 & 189 & 80 & 1 & 0 & 0.243 & 0.214 \\
\hline$K$ & + & 46 & 46 & 25 & 0.4 & 122 & 75 & 5 & 3 & 0.154 & 0.198 \\
\hline$L$ & - & 58 & 60 & 36 & 0.4 & 80 & 53 & 9 & 6 & 0.158 & 0.196 \\
\hline$M$ & + & 62 & 63 & 30 & 0.4 & 106 & 68 & 10 & 6 & 0.198 & 0.200 \\
\hline $\mathrm{N}$ & + & 54 & 57 & 19 & 0.3 & 83 & 59 & 6 & 4 & 0.222 & 0.164 \\
\hline $\mathrm{O}$ & - & 56 & 56 & 41 & 0.3 & 69 & 53 & 4 & 7 & 0.198 & 0.199 \\
\hline$P$ & - & 58 & 58 & 43 & 0.2 & 66 & 66 & 5 & 5 & 0.151 & 0.230 \\
\hline$Q$ & - & 61 & 58 & 24 & 0.1 & 14 & 65 & 0 & 0 & 0.163 & 0.162 \\
\hline Mean & & & & & & & & & & 0.193 & 0.192 \\
\hline
\end{tabular}

Table 3. Mean sister chromatid exchange (SCE) frequencies, standard deviations, p-values, correlation coefficients, and number of persons exposed to more than $100 \mathrm{mg} / \mathrm{m}^{3}$ of xylene and toluene and with a hygienic effect above 1.

\begin{tabular}{|c|c|c|c|c|c|c|c|}
\hline \multirow{3}{*}{ Exposure } & \multicolumn{4}{|c|}{ SCE frequency } & \multirow[b]{3}{*}{$p$} & \multirow[b]{3}{*}{$r$} & \multirow[b]{3}{*}{ N } \\
\hline & \multicolumn{2}{|c|}{ Exposed persons } & \multicolumn{2}{|c|}{ Referents } & & & \\
\hline & Mean & SD & Mean & SD & & & \\
\hline $\begin{array}{l}\text { Xylene }>100 \mathrm{mg} / \mathrm{m}^{3} \\
\text { Toluene }>100 \mathrm{mg} / \mathrm{m}^{3}\end{array}$ & $\begin{array}{l}0.210 \\
0.207\end{array}$ & $\begin{array}{l}0.048 \\
0.061\end{array}$ & $\begin{array}{l}0.201 \\
0.182\end{array}$ & $\begin{array}{l}0.030 \\
0.035\end{array}$ & $\begin{array}{l}0.39 \\
0.17\end{array}$ & $\begin{array}{l}-0.02 \\
-0.02\end{array}$ & $\begin{array}{r}10 \\
7\end{array}$ \\
\hline Hygienic effect $>1$ & 0.199 & 0.032 & 0.179 & 0.038 & 0.19 & 0.19 & 5 \\
\hline
\end{tabular}


Table 4. Structural and numerical chromosome abnormalities of the five workers with a hygienic effect above 1 and of their referents.

\begin{tabular}{|c|c|c|c|c|c|c|c|c|}
\hline \multirow{2}{*}{$\begin{array}{l}\text { Member } \\
\text { of pair }\end{array}$} & \multirow{2}{*}{$\begin{array}{c}\text { Abnormal } \\
\text { metaphases } \\
(\%)\end{array}$} & \multirow{2}{*}{$\begin{array}{l}\text { Metaphases } \\
(\mathrm{N})\end{array}$} & \multicolumn{4}{|c|}{ Structural aberrations (N) } & \multirow{2}{*}{$\begin{array}{l}\text { Aneuploids } \\
\text { (hyperdip- } \\
\text { loids only) }\end{array}$} & \multirow[b]{2}{*}{ Gaps } \\
\hline & & & $\begin{array}{l}\text { Trans- } \\
\text { locations }\end{array}$ & $\begin{array}{l}\text { Dele- } \\
\text { tions }\end{array}$ & $\begin{array}{l}\text { Inver- } \\
\text { sions }\end{array}$ & $\begin{array}{c}\text { Chromatid } \\
\text { breaks }\end{array}$ & & \\
\hline
\end{tabular}

\begin{tabular}{|c|c|c|c|c|c|c|c|c|}
\hline \multicolumn{9}{|l|}{ Exposed } \\
\hline $\begin{array}{l}A \\
B\end{array}$ & $\begin{array}{l}2.75 \\
0\end{array}$ & $\begin{array}{r}109 \\
97\end{array}$ & $\begin{array}{r}1 \\
\end{array}$ & 2 & - & - & 1 & - \\
\hline$B$ & & 97 & $\overline{2}$ & $\overline{3}$ & & - & - & 2 \\
\hline C & 7.07 & 99 & 2 & 3 & 1 & $-a$ & - & 5 \\
\hline $\mathrm{Db}$ & 4.00 & 100 & 1 & - & 1 & 2 & - & 3 \\
\hline \multirow[t]{2}{*}{$E$} & 3.03 & 99 & 1 & - & 1 & 1 & 1 & 1 \\
\hline & 3.37 & 504 & 5 & 5 & 3 & 3 & 2 & 11 \\
\hline \multicolumn{9}{|l|}{ Referent } \\
\hline A & 2.04 & 98 & - & 2 & - & - & - & 3 \\
\hline B & 3.16 & 95 & 1 & 1 & - & - & 1 & 2 \\
\hline C & 2.02 & 99 & 1 & 1 & 一 & - & - & 3 \\
\hline D & 8.00 & 100 & 1 & 2 & 1 & 20 & 1 & 3 \\
\hline \multirow[t]{2}{*}{$E$} & 3.06 & 98 & - & 2 & - & - & 1 & 2 \\
\hline & 3.67 & 490 & 3 & 8 & 1 & 2 & 3 & 13 \\
\hline
\end{tabular}

a An additional $9 p+$, with the origin of the extra material unknown.

b Constitutionally XYY.

c An additional long acentric fragment, the origin of which is unknown.

above 1 and their respective referents. The mean frequency of aberrant cells in the exposed workers was $3.4 \%$, while that of the referents was $3.7 \%$ (chi-square ( $\mathrm{df}=$ 1) $=0.007,0.90<p<0.95$ ) (table 4). When only structural aberrations were considered, the percentage of abnormal metaphases remained unchanged, 3.4 for the exposed persons, while it decreased to 3.1 for the referents.

The exposed worker of pair D had an extra $\mathrm{Y}$ chromosome in almost all of his metaphase plates; this occurrence probably represented a constitutional anomaly. We did not however look at the chromosomes of any other tissue than lymphocytes.

\section{Types of chromosome aberrations}

Of the eight translocations, three were reciprocal (one incomplete), one was dicentric, and four were of the tandem type. Two of the tandem translocations were between chromosomes 7 and 14, one in an exposed subject and one in a referent.

All the deletions were lacking their expected acentric fragments. As the cultures were grown for $72 \mathrm{~h}$, many cells may have been in their second division at the time of harvest, and thus the acentric fragments could have become lost in the previous mitosis. Of course, the fragments could have been lost during divisions occurring in vivo. The obtainment of first division metaphases usually requires the harvesting of cells after $48 \mathrm{~h}$ in culture. However, in order to get the same culturing interval for all the cultures being mailed from different areas, we had to chose 72 -h culturing.

Correlation between sister chromatid exchanges and chromosome breaks

The correlation coefficients for the frequencies of SCE and breaks were 0.49 for the exposed subjects and 0.09 for the referents for the 10 persons analyzed for SCE and structural aberrations. Neither of these two values of $r$ proved to be significantly different from $0\left(\mathrm{r}=0.49: \mathrm{t}_{\mathrm{r}}=1.93, \mathrm{r}=\right.$ $\left.0.09: t_{r}=0.16 ; t_{3: 0.975}= \pm 3.182\right)$.

\section{Discussion}

Most of the participants in our study had been employed in the paint industry for more than 10 a. Workers sensitive to different solvent actions, for example, effects on the central nervous system (CNS), are liable to have left a job in a solvent-ex- 
posed environment at an earlier date. There were, however, three persons in our study with extremely high exposures and relatively short durations of employment. They did not exhibit chromosome aberrations or SCE in excess of the other paint industry workers or their referents. On the other hand they all complained of CNS symptoms.

Both benzene and styrene are known to have reactive biotransformation products. The genotoxicity of styrene has been attributed to the epoxide metabolite styrene oxide (32). Benzene metabolites have been shown to bind covalently to DNA (deoxyribonucleic acid) in rats (20). The predominant pathways of toluene and xylene biotransformation end with the solvents being excreted in the urine as the glycine conjugates hippuric acid and methylhippuric acid. There are no indications of reactive intermediates in these degradation processes. However, less than $2 \%$ of the xylene and an even smaller fraction of the toluene retained in the human organism is hydroxylated at the aromatic nucleus (1, 28). Thus, the possibility of an epoxide intermediate being formed in small amounts cannot be excluded. Working with the autoradiographic technique and mice, Bergman (2) showed evidence of firmly bound metabolites of benzene and styrene in tissues after inhalation. On the other hand, toluene and xylene radioactivity had completely disappeared from the bodies of the mice in less than $48 \mathrm{~h}$, leaving no firmly bound metabolites.

Neither benzene, toluene, nor xylene changes the frequencies of SCE or chromosome aberrations in human lymphocytes in vitro (12). Our findings are compatible with these results. Some of the workers in our material were exposed to high concentrations of a solvent mixture having toluene or xylene as the main components. In spite of this, they showed neither more SCE nor more chromosome aberrations than their referents. This finding suggests that the solvent mixture used in the Swedish paint industry does not exert a pronounced genotoxic effect.

However, the paint industry workers were exposed not only to toluene or xylene, but to an average of seven different solvents. This situation allows for the possi- bility of interaction; a condition which would be difficult to assess due to the present lack of knowledge on solvent interactions. Until antagonistic effects can be ruled out, it is difficult to state with any certainty that this lack of a pronounced genotoxic effect also reflects a lack of effect of the solvents toluene and xylene.

The same reasoning applies to methylene chloride. The three workers with the greatest exposure, A, B and C, were all exposed to high levels of this solvent, which is known to be mutagenic in bacterial test systems (16) and to induce malignant cell transformation in rat embryo cells in vitro (24). As has already been pointed out, these workers did not show more SCE or chromosome aberrations than their referents. Only in the absence of antagonistic effects between different solvents could this phenomenon suggest that methylene chloride does not exert a genotoxic effect of great magnitude.

The lack of correlation between the frequencies of SCE and chromosome aberrations noted in this investigation has also been reported by others $(23,26)$. This finding could be anticipated, as the ability of various agents to induce $\mathrm{SCE}$ and chromosome aberrations is not absolutely correlated (34), and also the two mechanisms of induction are different $(11,18,33)$.

The incidence of XYY individuals in the general population is $1.2 / 1,000$ (9). The frequencies of SCE and chromosome aberrations in the exposed member of pair $D$ in our investigation, who was probably constitutionally XYY, showed no deviation from those of the other individuals. Seabright (27) in an investigation on the effect of $X$ rays on chromosome exchanges in individuals with abnormal sex chromosome complements, found no consistent difference between abnormal and normal karyotypes with respect to the mean number of breaks per cell. Sasaki et al (25), on the other hand, obtained an increased frequency of exchanges in the trisomic, but not in the normal cells, of a mosaic patient with $46 \mathrm{XY} / 47 \mathrm{XYY}$ after irradiation with $160 \mathrm{R} X$ rays in vitro.

One of the two translocations between chromosomes 7 and 14 were found in a referent and one in an exposed person. The break points, (qter;q12-3) and (pter; 
q22), respectively, were the same as those in cases $\mathrm{A}$ and $\mathrm{B}$ reported earlier by us (35). Whether the translocations are in fact reciprocal was not possible to determine. It seems likely to us that these translocations are in vitro effects, as we have never found them in any tissue but phytohemagglutinin-stimulated lymphocytes. However, there has been a report of a mentally retarded boy with a great number of trans locations between chromosomes 7 and 14 with the break points almost exclusively in $7 \mathrm{p} 13,7 \mathrm{q} 32$ and $14 \mathrm{q} 11$ in his peripheral lymphocytes, while no abnormalities could be found in his bone marrow (15). The authors considered it possible that it was a severe expression, in their patient, of a chromosome instability that also occurs in normal individuals, but they also speculated that persons with occasional translocations of this kind are heterozygous carriers of a hereditary disease with serious clinical symptoms.

\section{Acknowledgments}

We wish to thank engineers I-MI Andersson and G Rosen, who performed the exposure measurements. We also wish to thank nurses A Enekvist-Roos, I Burwall and G Nilsson, who helped us obtain some of the blood samples, and laboratory assistants $B$ Stellan and A Wallblom for their excellent technical help. We are grateful to Prof A Swensson for his critical reading of the manuscript.

The work was supported by grants from the Swedish Cancer Society and by funds from the Karolinska Institute.

\section{References}

1. Angerer J. Occupational chronic exposure to organic solvents: VII Metabolism of toluene in man. Int arch occup environ health 43 (1979) 63-67.

2. Bergman K. Whole-body autoradiography and allied tracer techniques in distribution and elimination studies of some organic solvents: Benzene, toluene, xylene, styrene, methylene chloride, chloroform, carbon tetrachloride and trichloroethylene. Scand $j$ work environ health 5 (1979): suppl 1.

3. Caspersson $T$, Lindsten $J$, Lomakka $G$, Wallman $H$, Zech L. Rapid identification of human chromosomes by TV-techniques. Exp cell res 63 (1970) $477-479$.

4. Caspersson $T$, Lomakka $G$, Zech $L$. The 24 fluorescence patterns of the human metaphase chromosomes - Distinguishing characters and variability. Hereditas 67 (1971) $89-102$.

5. Caspersson T, Lomakka G, Zech L, Issler $P$, Kudynowski J, Kvarnström $K$. Rapid techniques for counting and analysis of chromosome aberrations. Exp cell res 88 (1974) 427-428.

6. Fleig I, Thiess AM. Mutagenicity study of workers employed in the styrene and polystyrene processing and manufacturing industry. Scand $j$ work environ health 4 (1978): suppl 2, 254-258.

7. Forni A, Cappellini A, Pacifico E, Vigliani E. Chromosome changes and their evolution in subjects with past exposure to benzene. Arch environ health 23 (1971) 385-391.

8. Forni A, Pacifico E, Limonta A. Chromosome studies in workers exposed to benzene or toluene or both. Arch environ health 22 (1971) $373-378$.

9. Friedrich U, Nielsen J. Chromosome studies in 5,049 consecutive newborn children. Clin genet 4 (1973) 333-343.

10. Funes-Cravioto F, Zapata-Gayon C, Kolmodin-Hedman B, Lambert B, Lindsten $\mathrm{J}$, Norberg E, Nordenskjöld M, Olin R, Swensson Å. Chromosome aberrations and sisterchromatid exchange in workers in chemical laboratories and a rotoprinting factory and in children of women laboratory workers. Lancet 2 (1977) 322-325.

11. Galloway SIM, Wolff S. The relation between chemically induced sister-chromatid exchanges and chromatid breakage. Mutat res 61 (1979) 297--307.

12. Gerner-Smidt F, Friedrich U. The mutagenic effect of benzene, toluene and xylene studied by the SCE technique. Mutat res 58 (1978) 313-316.

13. Haglund $U$, Lundell $G$, Zech L, Ohlin J, Radioiodine administration in hyperthyroidism - A cytogenetic study. Hereditas 87 (1977) 85-98.

14. Hartwich G, Schwanitz G. Chromosomenuntersuchungen nach chronischer BenzolExposition. Dtsch Ned Wochenschr 97 (1972) $45-49$.

15. Hustinx TWJ, Scheres JMJC, Weemaes CMR, Ter Haar BGA, Janssen AH. Karyotype instability with multiple $7 / 14$ and $7 / 7$ rearrangements. Hum genet 49 (1979) 199 208.

16. Jongen WMF, Alink GM, Koeman JH. Mutagenic effect of dichloromethane on salmonella typhimurium. Mutat res 56 (1978) 245-248.

17. Kahn H, Kahn MH. Cytogenetische Untersuchungen bei chronischer Benzolexposition. Arch toxicol 31 (1973) 39-49.

18. Kato H. Spontaneous and induced sister chromatid exchanges as revealed by the BUdR-labelling method. Int rev cytol 49 (1977) $55-97$.

19. Lambert B, Lindblad A, Nordenskjöld M, Werelius B. Increased frequency of sister 
chromatid exchanges in cigarette smokers. Hereditas 88 (1978) 147-149.

20. Lutz WK, Schlatter C. Mechanism of the carcinogenic action of benzene: Irreversible binding to rat liver DNA. Chem biol interact 18 (1977) 241-245.

21. Meretoja T, Järventaus H, Sorsa M, Vainio H. Chromosome aberrations in lymphocytes of workers exposed to styrene. Scand $j$ work environ health 4 (1978): suppl 2 , $259-264$.

22. Perry P, Wolff S. New method for the differential staining of sister chromatids. Nature 251 (1974) 156-158.

23. Popescu NC, Turnbull D, Dipaolo JA. Sister chromatid exchange and chromosome aberration analysis with the use of several carcinogens and non-carcinogens. J natl cancer inst 59 (1977) 289-292.

24. Price PJ, Hassett CM, Mansfield JI. Transforming activities of trichloroethylene and proposed industrial alternatives. In vitro 14 (1978) 290-293.

25. Sasaki MS, Tonomura A, Matsubara S. Chromosome constitution and its bearing on the chromosomal radiosensitivity in man. Mutat res 10 (1970) 617-633.

26. Schubert I, Sturelid S, Döbel P, Rieger R. Intra-chromosomal distribution patterns of mutagen-induced SCEs and chromatid aberrations in reconstructed karyotypes of Vicia faba. Mutat res 59 (1979) 27-38.
27. Seabright M. Noninvolvement of the human $\mathrm{X}$ chromosome in X-ray-induced exchanges. Cytogenet cell genet 12 (1973) $342-356$.

28. Sedivec V, Flek J. The absorption, metabolism and excretion of xylenes in man. Int arch occup environ health 37 (1976) 205217.

29. Snedecor G. Statistical methods. The Iowa State University Press, Ames, IA 1956, p 173.

30. Tough IM, Court Brown WM. Chromosome aberrations and exposure to ambient benzene. Lancet 1 (1965) 684.

31. Ulfvarson U. Chemical hazards in the paint industry. In: International symposium on the control of air pollution in the working environment. The Work Environment Fund, Stockholm 1977, pp 66-75.

32. Vainio $H$. Vinyl chloride and vinyl benzene (styrene) - metabolism, mutagenicity and carcinogenicity. Chem biol interact 22 (1978) $117-124$.

33. Wolff S. Sister chromatid exchanges. Annu rev genet 11 (1977) 183-201

34. Wolff S, Carrano AV. Report of the workshop on the utility of sister-chromatid exchange. Mutat res 64 (1979) $53-56$.

35. Zech I, Haglund U. A recurrent structural aberration, $t(7 ; 14)$, in phytohemagglutininstimulated lymphocytes. Hereditas 89 (1978) $69-73$.

Received for publication: 5 June 1980 